\title{
Effect of Cardioselective Beta Blocker on Lisinopril Treated Isolated Rabbit's Heart
}

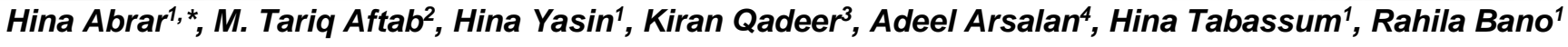 \\ ${ }^{1}$ Dow College of Pharmacy, Dow University of Health Sciences, Karachi, Pakistan \\ ${ }^{2}$ Department of Pharmacology, Islam Medical College, Sialkot 51480, Pakistan \\ 3Institute of Pharmaceutical Sciences, Jinnah Sindh Medical University, Karachi, Pakistan \\ ${ }^{4}$ Faculty of Pharmacy, Ziauddin University, Karachi, Pakistan
}

\begin{abstract}
Authors' Contributions
1 Conception \& Study Design, Data Collection, Data Analysis.

2 Conception \& Study Design

3,6,7 Drafting, Critical Review.

4 Data Analysis, Drafting.

5 Data Analysis.
\end{abstract}

\section{Article info.}

Received: December 19, 2019

Accepted: January 22, 2020

Funding Source: Nil

Conflict of Interest: Nil

Cite this article: Abrar $\mathrm{H}, \mathrm{Aftab} M T$, Yasin $\mathrm{H}$,

Qadeer K, Arsalan A, Tabassum H, Bano R.

Effect of Cardioselective Beta Blocker on

Lisinopril Treated Isolated Rabbit's Heart.

RADS J Pharm Pharm Sci. 2019; 7(4): 186-

190.

*Address of Correspondence Author:

hina.abrar@duhs.edu.pk

\section{ABSTRACT}

Background: Certain drugs produce unpredictable responses when used in emergency conditions. These variable outcomes may be harmful or beneficial for the patient.

Objective: This study has been conducted to evaluate the pharmacodynamic interaction between angiotensin converting enzyme inhibitor and metoprolol, a selective blocker of $\beta_{1}$ receptors. Cardioselective beta blockers are commonly used to treat hypertension, arrhythmias and ischemic heart disease.

Method: In this study, 20 healthy male rabbits were selected and divided into two groups. Effective dose of Lisinopril $(10 \mathrm{mg} / \mathrm{kg})$ was administered orally via oral feeding, for 9 days. By using Langendroff's technique, the effects of metoprolol were observed in isolated hearts.

Result: The data showed that the effective dose of Lisinopril $(10 \mathrm{mg} / \mathrm{kg}$ daily orally) increases the inotropic and chronotropic effects of metoprolol significantly $(p<0.05)$.

Conclusion: Therefore, lisinopril, an inhibitor of angiotensin converting enzyme may increase the response of cardioselective beta blocker metoprolol in isolated rabbit's heart.

Keywords: Pharmacodynamic interaction, ionotropic effect, chronotropic effect, Langendroff's technique.

\section{INTRODUCTION}

Metoprolol is a selective $\beta_{1}$-receptor antagonist that acts through deactivation of adenylyl cyclase. These antagonists thus affect various cardiovascular events by reducing cardiac output, coronary flow, heart rate, and blood pressure while improving the myocardial oxygen consumption. They also cause reduction a in arterial blood pressure by reducing cardiac output and decrease rennin release from the juxtaglomerular cells of kidney. The $\beta_{1}$-adrenoceptor antagonist has an antiarrhythmic effect on heart mainly by increasing the refractory period of $A V$ node [1].
ACE inhibitors, Lisinopril decrease angiotensin concentration in the blood which decreases the angiotensin dependent $\mathrm{Ca}^{++}$ion concentration in cardiac muscle and thus inhibits myocardial contractility. With intact baroreceptor activity, angiotensin also causes reflex bradycardia. ACE inhibitors also decrease vascular permeability of endothelium in large arteries and decrease spaces in the aorta, coronary artery and peripheral arteries [2]. These are the general effects of individual drugs but when these drugs are administered concomitantly, they may affect the responses of each other [3-5]. In this study the response of a cardioselective drug 
metoprolol in lisinopril treated isolated rabbits heart has been explored. This study has great clinical importance for cardiac patients who have a history of prolonged use of lisinopril and also need to administered another cardioselective drug specially metoprolol.

\section{MATERIALS AND METHODS}

\section{Animal Selection}

In this study, ten healthy male rabbits weighing $1 \mathrm{~kg}$ to $1.2 \mathrm{~kg}$ has been selected. Each animal was kept in separate cage under controlled climatic condition during entire study in an alternating 12 hours light and dark cycle. All animals had full access to water and standard laboratory food ad libitum. All the animals have been divided into two groups, each comprised of five animals. The nutrient and oxygen were provided by McEwens solution.

\section{Ethical Approval}

The study was approved by the Ethical Committee of Baqai Medical University. All the animals were housed under controlled environment in the animal house of Baqai Medical University, Karachi.

\section{Drug Administration}

First group was treated with normal saline with similar dose and time period and served as control while the second group treated with lisinopril $(10 \mathrm{mg} / \mathrm{kg}, 9$ days). After 24 hours of the last dose, all animals have been sacrificed and their hearts were isolated according to the designed protocol for further study [6-8].

\section{Effect of Drug on Isolated Heart}

Langendroff technique [9] has been used to observe the effect of metoprolol after the administration of lisinopril causing up or down regulation of the receptors. In Langendroff technique, isolated heart was incorporated with aorta, to measure various cardiac responses like heart rate, force of contraction, coronary blood flow and cardiac tissue stimulations, etc. The basic principle is to maintain cardiac activity by perfusing the heart via the coronary arteries using an aortic cannula inserted into the ascending aorta. Perfusion solution is delivered to the heart in a retrograde manner via this cannula.

\section{Statistical Analysis}

The data were treated with the Statistical Package for Social Science version 16 and the descriptive statistics were presented based on the distribution to calculate mean and standard error mean (SEM).

\section{RESULTS}

The effect of metoprolol on force and rate of cardiac contraction in terms of amplitude (measured as length of beats) and rate of contraction, respectively has been observed in this study.

\section{Assessment of Metoprolol Effect on Isolated Rabbit Heart}

Administration of $0.1 \mathrm{mg}$ and $1 \mathrm{mg}$ of metoprolol showed the percentage changes in rate and amplitude from normal (Table 1). The mean values of amplitude at dose $0.1 \mathrm{mg}$ of metoprolol was found as $-11.63 \pm 1.2$ and rate was $-21.14 \pm 1.7$, while at dose $1 \mathrm{mg}$ the amplitude was further decreased to $-20.01 \pm$ 2.7 and rate was $-29.41 \pm 2.3$ as compared to normal.

Table 1. Effect of metoprolol on isolated rabbit heart.

\begin{tabular}{|c|c|c|}
\hline \multirow{2}{*}{ Dose } & \multicolumn{2}{|c|}{ Percentage Change } \\
\cline { 2 - 3 } & Force of Contraction & Rate $^{+}$ \\
\hline $0.1 \mathrm{mg}$ & $-11.63 \pm 1.2^{*}$ & $-21.14 \pm 1.7$ \\
\hline $1 \mathrm{mg}$ & $-20.01 \pm 2.7$ & $-29.41 \pm 2.3$ \\
\hline
\end{tabular}

* Mean \pm SEM; + = No. of beats $/ \mathrm{min} ; n=$ No. of observation; $(n=5)$

Table 2. Effect of metoprolol on isolated rabbit heart after treatment of lisinopril.

\begin{tabular}{|c|c|c|}
\hline \multirow{2}{*}{ Dose } & \multicolumn{2}{|c|}{ Percentage Change } \\
\cline { 2 - 3 } & Force of Contraction & Rate $^{+}$ \\
\hline $0.1 \mathrm{mg}$ & $-11.98 \pm 1.7^{*}$ & $-22.43 \pm 1.6$ \\
\hline $1 \mathrm{mg}$ & $-23.05 \pm 2.6$ & $-29.99 \pm 2.2$ \\
\hline
\end{tabular}

${ }^{*}$ Mean \pm SEM $;+=$ No. of beats $/ \mathrm{min} ; n=$ No. of observation; $(n=5)$

Evaluation of Effect of Metoprolol on Isolated Rabbit Heart After Treatment of Lisinopril

The changes in percentage of amplitude and rate after administration of lisinopril are given in Table 2 and then treated with two doses of metoprolol. The mean values observed for the force of contraction which decreased upto $-11.98 \pm 1.7$ and similarly rate was decreased upto $-22.43 \pm 1.6$ while amplitude and 
rate after $1 \mathrm{mg}$ of metoprolol was further decreased upto $-23.05 \pm 2.5$ and $-29.99 \pm 2.2$, respectively after the treatment of lisinopril.

\section{Comparison of Effect of Metoprolol on Amplitude, Individually and with Treatment of Lisinopril}

The effect of metoprolol $(0.1 \mathrm{mg}$ and $1 \mathrm{mg}$ ) were given in Table $\mathbf{3}$ when administered with the treatment of lisinopril shown a decrease in the amplitude upto $-11.98 \pm 1.7$ shows statistical significance $(p<0.05)$ as compared to the amplitude calculated in response to metoprolol alone i.e. -11.63 \pm 1.2. The amplitude at $1 \mathrm{mg}$ of metoprolol with lisinopril was further found to be decreased as -23.05 \pm 2.6 with statistical significance of $\mathrm{p}<0.05$ as compared with metoprolol independently i.e. $-20.01 \pm$ 2.

Table 3. Comparison of effect of metoprolol on amplitude after administration of lisinopril.

\begin{tabular}{|c|c|c|c|}
\hline Dose & $\begin{array}{c}\text { Metoprolol } \\
\text { Alone }\end{array}$ & $\begin{array}{c}\text { Metoprolol } \\
\text { with } \\
\text { Lisinopril }\end{array}$ & Significance \\
\hline $0.1 \mathrm{mg}$ & $-11.63 \pm 1.2^{*}$ & $-11.98 \pm 1.7$ & $\mathrm{p}<0.05$ \\
\hline $1 \mathrm{mg}$ & $-20.01 \pm 2.7$ & $-23.05 \pm 2.6$ & $\mathrm{p}<0.05$ \\
\hline
\end{tabular}

* Mean \pm SEM; + = No. of beats $/ \mathrm{min} ; \mathrm{n}=$ No. of observation; $(n=5)$

Table 4. Comparison of effect of metoprolol on rate after chronic administration of lisinopril.

\begin{tabular}{|c|c|c|c|}
\hline Dose & $\begin{array}{c}\text { Metoprolol } \\
\text { Alone }\end{array}$ & $\begin{array}{c}\text { Metoprolol } \\
\text { with } \\
\text { Lisinopril }\end{array}$ & Significance \\
\hline $0.1 \mathrm{mg}$ & $-21.14 \pm 1.7^{*}$ & $-22.43 \pm 1.6$ & $\mathrm{p}<0.05$ \\
\hline $1 \mathrm{mg}$ & $-29.41 \pm 2.3$ & $-29.99 \pm 2.2$ & $\mathrm{p}>0.05$ \\
\hline
\end{tabular}

${ }^{*}$ Mean \pm SEM; + = No. of beats $/$ min; $n=$ No. of observation; $(n=5)$

\section{Comparison of Effect of Metoprolol on Rate Individually and with Treatment of Lisinopril}

Table 4 compares the mean values observed on rate after administration of metoprolol with or without lisinopril. The rate was decreased upto $-22.43 \pm 1.6$ when $0.1 \mathrm{mg}$ metoprolol administered to the isolated rabbit heart with lisinopril having statistical significance of $(p<0.05)$, while the rate was observed as $-21.14 \pm 1.7$ in case of metoprolol alone. At $1 \mathrm{mg}$ of metoprolol and lisinopril the rate was $-29.99 \pm 2.2$ which is statistically insignificant when compared to the rate after independent administration of metoprolol i.e. $-29.41 \pm 2.3$.

\section{DISCUSSION}

A physician required the predication of responses when multiple drug administered to the patients but sometimes the outcomes of these combination are totally or to the large extent different. Several studies have been carried out which prove the variation in cardiac receptor density after the administration of cardio selective drugs $[5,10,11]$.

It was also investigated that in congestive heart failure ACE inhibitor along with $\beta$ receptor antagonist restore low and high frequency harmonic oscillations in muscle sympathetic nerve activity $[12,13]$ which was exerting beneficial effects on sudden death and disease progression in congestive heart failure and this combination is also very helpful in improving left ventricular dysfunctions [14, 15]. It was also reported by many researchers that ACE inhibitors along with the beta-blockers produces a synergistic responses on cardiac remodeling or dilated cardiomyopathy [1618]. It was also reported that variations in the sympathetic derive observed in cardiac failure. In these types of observation physician may sometimes prescribe Beta blocker to reduces the cardiac effects of epinephrine [19, 20]. Many clinical trials are also conducted to prove the additive role of beta-blockers with ACE inhibitors [21].

In this study it was investigated that altered responses of metoprolol on lisinopril treated heart. Chronic administration of lisinopril improves the $\beta$ receptor density in the heart. Previous studies have been conducted by Mallem et al., Sethi et al., De Tommasi et al., Gilbert and Port, Akashi et al., and Bristow et al. also support this concept [22-27] and hence proved by our data. The force of contraction of cardiac muscles and heart rate both are decreased by chronic administration of lisinopril and then metoprolol i.e. more ionotropism and choronotropism seen when metoprolol administered to lisinopril treated heart. In other words, we can say that lisinopril increase the response of cardioselective beta blocker metoprolol. 


\section{CONCLUSION}

Therefore, lisinopril, an inhibitor of angiotensin converting enzyme may increase the response of cardioselective beta blocker metoprolol in isolated rabbit's heart. These types of altered responses that are produced by ACE inhibitors are especially considerable in the emergency treatment of CHF in which ACE inhibitors are the drug of choice for long term treatment of disease and metoprolol was also administered to improve heart rate. There is a further need to explore the use of more advanced and sophisticated techniques to estimate further responses and also to evaluate the receptor density.

\section{REFERENCES}

1. Dale MM, Rang HP, Ritter JM, Moore PK. Heart, In: Pharmacology, Rang HP editor, $9^{\text {th }}$ edition. Elsevier, 2019; pp. 273.

2. Dandan HR. The rennin and angiotensin, In: The Pharmacological basis of therapeutics, Brunton LL, Dandan $\mathrm{RH}$, Knollmann BC editors, $13^{\text {th }}$ edition. McGraw-Hill, New York, 2019; pp. 795-6.

3. Rastogi S, Sharov VG, Mishra S, Gupta RC, Blackburn B, Belardinelli L, et al. Ranolazine combined with enalapril or metoprolol prevents the LV dysfunction and remodeling. Am J Physiol Heart Cric Physiol. 2008; 295(5):H2149-55.

4. Zeltner R, Polaik R, Stiasny B, Schmieder RE, Schulze BD. Renal and cardiac effects of antihypertensive treatment with ramipril vs. metoprololin autosomal dominant polycystic kidney disease. Nephrol Dial Transplant. 2008; 23(2):5739.

5. Igase M, Kohara K, Nagai T, Miki T, Ferrario CM. Increased expression of angiotensin converting enzyme 2 in conjunction with reduction of neointima by angiotensin II type 1 receptor blockade. Hypertens Res. 2008; 31(3):553-9.

6. Ishiyama $\mathrm{Y}$, Gallagher PE, Averill DB, Tallant EA, Brosnihan KB, Ferrario CM. Upregulation of angiotensin-converting enzyme 2 after myocardial infarction by blockade of angiotensin II receptors, Hypertension. 2004; 43(5):970-6.

7. Abrar H, Aftab MT. Study of alteration of adrenergic receptor response by chronic use of lisinopril: An ACE inhibitor. Pak J Pharm Sci. 2013; 26(2):421-3.

8. Abrar H, Yasin H, Khalid S, Perveen R, Tabassum $\mathrm{H}$, Fatima K. Reduction of cardiac effect of propranolol in lisinopril treated isolated rabbit heart. World J Pharm Sci. 2018; 6(1):24-8.
9. Langendroff $O$. Untersuchungen am Uberleberden Saiigertierzen Pflugrers. Arch Ges Physion. 1895; 61:291-332.

10. Nap A, Belterman CN, Mathy MJ, Balt JC, Pfaffendorf $M$, van Zwieten PA. Impaired neuronal and vascular responses to angiotensin II in a rabbit congestive heart failure model. J Renin Angiotensin Aldosterone Syst. 2003; 4(4):220-7.

11. Kitchen I. Text Book of In Vitro Practical Pharmacology, $1^{\text {st }}$ edition, 1984; pp. 101-11.

12. Kubo $T$, Azevedo ER, Newton GE, Picton $P$, Parker JD, Floras JS. $\beta$-blocker restores sympethetic rhythmicity in human heart failure. Circ J. 2011; 75(6):1400-8.

13. Chali JK, Dunselman P, Waagstein F, Goldstein S, Gottieb SS, Deedwania PC, et al. Consistency of the benificial effect of metoprolol sucinate extended release across a wide range dose of angiotensin converting enzyme inhibitors and digitalis. J Card Fail. 2004; 10(6):452-9.

14. Hara $Y$, Hamada $M$, Shigmatsu $Y$, Suzuki $M$, Kodama K, Kuwahara $\mathrm{T}$, et al. Effect of betablocker on left ventricular function and natriuretic peptides in patients with chronic heart failure treated with angiotensin-converting enzyme inhibitor. Jpn Circ J. 2000; 64(5):365-9.

15. Sabbah HN, Shimoyama H, Kono T, Gupta RC, Sharov VG, Scicli G, et al. Effect of long term monotherapy with enalapril, metoprolol and digoxin on the progression of left ventricular dysfunction and dilation in dogs with reduced ejection fraction. Circulation. 1994; 89(6):2852-9.

16. Hamada M, Hara Y, Ohtsuka T, Suzuki J, Saeki H, Ogimoto $\mathrm{A}$, et al. Effect of addition of beta blocker on left ventricular remodeling and prognosis in patients with dilated cardiomyopathy treated with angiotensin-converting enzyme inhibitor. J Cardiovasc Pharmacol. 2003; 41(1):S5-10.

17. Seeland U, Schaffer A, Selejan S, Hohl M, Reil JC, Muller P, et al. Effect of AT1 and beta-adrenergic receptor antagonist on TGF-beta1-induced fibrosis in transgenic mice. Eur $\mathrm{J}$ Clin Invest. 2009; 39(10):851-9.

18. Laviolle B, Pape D, Turlin B, Bellisant E. Direct effects of three combinations of enalapril, metoprolol and spironolactone on cardiac remodeling in dilated cardiomyopathic hamsters. $J$ Card Fail. 2006; 12(9):752-8.

19. Wang Y, Seto SW, Golledge J. Angiotensin II, sympathetic nerve activity and chronic heart failure. Heart Fail Rev. 2014; 19(2):187-98.

20. Azevedo ER, Mak S, Floras JS, Parker JD. Acute effects of angiotensin-converting enzyme inhibition versus angiotensin II receptor blockade on cardiac 
sympathetic activity in patients with heart failure. Am J Physiol Regul Integr Comp Physiol 2017; 313: R410-R417.

21. Hoffman J, Grimm W, Maisch B. Beta blockers in therapy of chronic heart failure. Herz. 2002; 27(2):150-65.

22. Gilbert EM, Port JD. Deactivation of sympethetic nervous system in patient with chronic congestive heart failure. Curr Cardiol Rep. 2000; 2(3):225-32.

23. Mallem MY, Reculeau O, Le Coz O, Gagny M, Desfontis JC. Low affinity state beta1adrenoreceptor-induced vasodilation in SHR. Peptides. 2005; 26(8):1463-7.

24. Bristow MR, Hershberger RE, Port JD, Feldman AM. Beta adrenergic pathway in non failing and failing human myocardium. Circulation. 1990; 82(1):12-25.
25. Akashi $\mathrm{Y}$, Tonabe K, Osada N, Semijima H, Seki A, Yokoyama $Y$, et al. Effect of ACE inhibitor on sympathetic heart rate response during exercise in the early phase of myocardial infarction. J Cardiol. 2000; 36(4):221-9.

26. De Tommasi $E$, lacoviello $M$, Romito $R$, Ceconi C, Guida P, Massari F, et al. Comparison of the effect of valsartan and lisinopril on autonomic nervous system activity in chronic heart failure. Am Heart J. 2003; 146(5):E17.

27. Sethi R, Shao Q, Ren B, Saini HK, Takeda N, Dhalla NS. Changes in beta adrenoceptors in heart failure due to myocardial infaction are attenuated by blockade of renin-angiotensin system. Mol Cell Biochem. 2004; 263(1-2):11-20. 